\title{
STRUKTUR DAN UNSUR KEBAHASAAN TEKS FABEL KELAS VII SMP NEGERI PEMBANGUNAN PADANG
}

\author{
Oleh \\ Yesi Septianingsih ${ }^{1}$, Afnita $^{2}$ \\ Program Studi Bahasa Indonesia FBS UNP \\ Email: yesi.septianingsih09@gmail.com ${ }^{1,}$ afnitaaunp@gmail.com $^{2}$
}

\begin{tabular}{l}
\hline Article History \\
\hline Received : May 2020 \\
Accepted : June 2020 \\
Published : July 2020 \\
\hline Keywords \\
\hline Struktur dan unsur \\
kebahasaan, teks fabel
\end{tabular}

\begin{abstract}
The purpose of this study is to describe the errors that occur in grade VII students of the SMP Negeri Pembangunan Padang. The population in this study were eighth grade students of SMP Negeri Pembangunan Padang. This type of research is qualitative, the research analyzed does not use statistics. The instrument of this research was the research itself and the fable text written by VII grade students of the SMP Negeri Pembangunan Padang. Data collection techniques in this research is by means of documentation. The data analysis technique of this research went through several processes, namely (1) reading fable texts of students' work, (2), reading fables of students' work, (3) looking for language errors (use of spelling) in fable texts of students' work, (4) grouping errors free fable text of student work, and (5) discusses errors in fable text of student work. The results of the first study, the structure in the fable text of VII students of SMP Negeri Pembangunan Padang 99\% was made correctly and properly. Second, non-linguistic errors in fable texts written by VII grade students of SMP Negeri Pembangunan Padang, namely mistakes in the use of capital letters, mistakes in prepositions of use, and errors in making particles. Errors found were published, (1) errors in capital letters using 175 cases of errors, (2) errors in prepositions as many as 50 cases of errors, and (3) Third, steps to overcome errors in writing fable texts for VII grade students of SMP Negeri Pembangunan Padang.
\end{abstract}


adalah kualitatif, yaitu penelitian yang dianalisis tidak menggunakan statistik. Instrumen penelitian ini adalah penelitian itu sendiri dan teks fabel karya siswa kelas VII SMP Negeri Pembangunan Padang. Teknik pengumpulan data dalam penelitian ini adalah dengan cara dokumentasi. Teknik analisis data penelitian ini melalui beberapa proses, yaitu (1) membaca teks fabel karya siswa, (2), membaca teks fabel karya siswa, (3) mencari kesalahan bahasa (penggunaan ejaan) dalam teks fabel karya siswa, (4) mengelompokkan kesalahan bebas teks fabel karya siswa, dan (5) membahas kesalahan dalam teks fabel karya siswa. Hasil penelitian pertama, struktur dalam teks fabel siswa VII SMP Negeri Pembangunan Padang 99\% dibuat dengan benar dan baik. Kedua, kesalahan tidak kebahasaan dalam teks fabel karya siswa kelas VII SMP Negeri Pembangunan Padang, yaitu kesalahan dalam penggunaan huruf kapital, kesalahan dalam preposisi penggunaan, dan kesalahan dalam pembuatan partikel. Kesalahan yang ditemukan diterbitkan, (1) kesalahan dalam huruf kapital menggunakan 175 kasus kesalahan, (2) kesalahan dalam preposisi sebanyak 50 kasus kesalahan, dan (3) Ketiga, langkah-langkah untuk mengatasi kesalahan dalam menulis teks fabel untuk siswa kelas VII SMP Negeri Pembangunan Padang. 


\section{A. Pendahuluan}

Latar belakang pemilihan judul artikel tersebut adalah karena SMP Negeri Pembangunan Padang telah menggunakan kurikulum 2013 yang berbasis teks. Walaupun kurikulum yang digunakan untuk pelajaran Bahasa Indonesia berbasis teks, dalam karya siswa masih sering ditemukan kesalahan berbahasa. Itu terjadi karena masih banyak siswa yang menganggap kegiatan menulis adalah hal mudah. Selain itu, siswa juga merasa sulit menemukan kosa kata yang tepat ketika akan menulis serta sulitnya menentukan gagasan atau topik yang akan ditulis. Hal ini disebabkan karena siswa yang tidak senang membaca. Salah satu kesalahan paling sederhana yang sering dilakukan siswa adalah siswa tidak memperhatikan penggunaan ejaan dalam menulis. Kesalahan penggunaan ejaan ini dapat mengurangi kualitas tulisan. Hal ini mengakibatkan terhambatnya ketercapaian pesan atau gagasan yang ingin disampaikan penulis. Kegiatan menulis memang tidak semudah yang dipikirkan karena untuk dapat menulis dengan baik seseorang harus sering berlatih, seperti pendapat dari Suhendar (1993) yaitu bahwa keterampilan menulis tidak datang secara otomatis, melainkan harus melalui proses latihan yang teratur dan banyak.

Tidak jarang akan ditemukan berbagai kesalahan berbahasa dalam teks fabel karya siswa karena kurangnya siswa membaca dan minimnya pengetahuan siswa terhadap struktur kebahasaan, seperti penelitian yang telah dilakukan oleh Safitri (2018) yang menemukan kesalahan penulisan unsur kebahasaan oleh siswa, meliputi kesalahan menggunakan huruf kapita, kesalahan menuliskan kata depan, dan kesalahan menulis partikel. Analisis kesalahan berbahasa dalam teks fabel ini juga diteliti oleh Reistanti (2017) yang hasil penelitiannya adalah terdapat kesalahan yang terbagi menjadi tiga tipe kesalahan, meliputi kesalahan bidang fonologi 33,33\%, kesalahan bidang morfologi $14,03 \%$, serta kesalahan bidang sintaksis $52,63 \%$. Kesalahan sintaksis terdapat 30 kesalahan atau 52,63\% dari kesalahan dan merupakan tipe kesalahan yang paling dominan. Reistanti juga mengemukakan 2 dominan sumber kesalahan berbahasa yaitu transfer intralingual dan transfer interlingual.

Peneliti menetapkan teks fabel karya siswa sebagai objek penelitiannya 
karena penelitian yang serupa belum terlalu banyak dari pada penelitian dari teks-teks lainnya.

\section{B. Metode Penelitian}

Jenis penelitian ini adalah kualitatif, yaitu penelitian yang dianalisis dengan tidak menggunakan statistik. Tujuan dari penelitian ini adalah untuk mendeskripsikan kesalahan berbahasa siswa kelas VII SMP Negeri Pembangunan Padang. Populasi dalam penelitian ini adalah siswa kelas VII SMP Negeri Pembanguanan Padang.

Instrumen penelitian ini adalah peneliti sendiri dan teks fable karya siswa kelas VII SMP Negeri Pembangunan Padang. Teknik pengumpulan data dalam penelitian ini adalah dengan cara dokumentasi. Teknik penganalisisan data penelitian ini melalui beberapa proses, yaitu (1) membaca teks fable karya siswa, (2), memahami teks fable karya siswa, (3) mencari kesalahan berbahasa (penggunaan ejaan) dalam teks fable karya siswa, (4) mengelompokkan kesalahan berbahasa teks fabel karya siswa. Dan (5) menyimpulkan kesalahan berbahasa teks fable karya siswa.
Data yang digunakan dalam penelitian ini sebanyak 20 buah teks fabel karya siswa kelas VII SMP Negeri Pembanguanan Padang. Inidikator yang digunakan adalah kesalahan unsur kebahasaan dalam teks fabel karya siswa kelas VII SMP Negeri Pembanguanan Padang, yang meliputi kesalahan penggunaan huruf kapital, kesalahan penulisan kata depan, dan kealahan penulisan partake terhadap teks fabel karya siswa kelas VII SMP Negeri Pembangunan Padang.

\section{Hasil Penelitian dan Pembahasan}

Bagian ini menjelaskan mengenai temuan penelitian yang didapatkan dari teks fabel karya siswa kelas VII SMP Negeri Pembangunan Padang. Tahun ajaran 2019-2020. Ada dua hasil penelitian yang dijelaskan pada bagian ini, yaitu (1) karakteristik struktur teks fabel karya siswa kelas VII SMP Negeri Pembangunan Padang, dan (2) unsur kebahasaan teks fabel karya siswa kelas VII SMP Negeri Pembangunan Padang.

Peneliti menyajikan hasil penelitian dan pembahasan dalam bentuk data karakteristik struktur teks fabel karya 
siswa kelas VII SMP Negeri Pembangunan Padang, dan data kesalahan berbahasa dalam teks fabel karya siswa kelas VII SMP Negeri Pembangunan Padang tahun ajaran 2019-2020 serta langkah-langkah untuk mengatasi kesalahan berbahasa siswa SMP Negeri Pembangunan Padang tahun ajaran $2019-2020$.

Berdasarkan penelitian yang dilakukan terhadap 15 teks fabel karya siswa kelas VII SMP Negeri Pembangunan Padang ditemukan 121 kalimat dan 1549 kata.

1. Struktur Teks Fabel Karya Siswa VII SMP Negeri Pembangunan Padang

Hasil dari penelitian yang dilakukan terhadap 15 teks fabel karya siswa kelas VII SMP Negeri Pembangunan Padang didapatkan 4 struktur teks fabel, yaitu orientasi, komplikasi, resolusi, dan koda.

Dari 15 teks fabel karya siswa kelas VII SMP Negeri Pembangunan Padang ditemukan sebuah teks fabel yang tidak memiliki koda, dan 15 teks fabel memiliki stuktur orientasi, komplikasi, dan resolusi.
Di bawah ini adalah data hasil temuan dan pembahasan kesalahan berbahasa dalam teks fabel kelas VII SMP Negeri Pembanguanan Padang tahun ajaran 2019-2020.

1. Kesalahan Penggunaan Huruf Kapital a. dia tampak senang karena tidak ada petani yang menjaga ladangnya.

Kesalahan data (a) terdapat pada teks fabel karya siswa yang berinisial CA. Kesalahannya terdapat pada penggunaan huruf d pada kata "dia", seharusnya adalah huruf kapital D karena kata "dia" terdapat di awal kalimat. Kesalahan serupa juga terdapat pada siswa berinisial RA, ZA, FI, $\mathrm{NN}, \mathrm{MR}, \mathrm{RH}$, dan KT.

b. sebuah ladang gandum dan kuda Kesalahan pada data (b) terdapat pada teks fabel karya siswa yang berinisial RA. Kesalahannya adalah huruf kapital di setiap kata pada kalimat data (b) yang seharusnya ditulis seperti "Sebuah Ladang Gandum dan Kuda" karena kalimat di atas adalah judul teks fabel karya siswa. Kesalahan serupa juga terdapat pada siswa 
berinisial CA, ZA, FI, NN, MR, D, dan $\mathrm{RH}$.

c. Seekor kudA sedAng BerjAlAn dAri sebuAh 1Ading gAndum menuju sebuAh hutAn yang lebAt.

Kesalahan pada data (c) terdapat pada teks fabel karya siswa yang berinisial ZS. Kesalahannya adalah huruf kapital yang terdapat di tengah kata dalam kalimat di atas, seperti kata "BerjAlAn" yang seharusnya ditulis "berjalan" dan beberapa kata yang serupa di atas, yang seharusnya huruf kapital tidak diperbolehkan untuk diletakkan di tengah kata dalam suatu kalimat. Kesalahan yang sama juga terdapat pada siswa yang berinisial ZA, FI, MZ, D, RH, PN, dan KT.

2. Kesalahan Penulisan Kata depan

a. Vitu pun menolong tuvi dan membawanya pulang kerumah.

Pada kalimat di atas terdapat kesalahan menulis kata depan oleh siswa berinisial CA, yaitu pada kata "kerumah" yang seharusnya kata depan "ke" dan kata "rumah" dipisah menjadi "ke rumah" karena menunjukan tempat. Kesalahan serupa juga terdapat pada siswa berinisial FI, NN, DN, MR, RS, TK, dan NH. b. Ketika berada diladang gandum ada seekor harimau sedang tertidur.

Kesalahan penggunaan kata depan pada kalimat di atas terdapat pada teks fabel siswa berinisial MR,yaitu pada kata "diladang" yang seharusnya kata depan "di" dan kata "ladang" dipisah, menjadi “di ladang”. Kesalahan yang sama juga terdapat pada teks fabel siswa yang berinisial MZ, D, RH, PN, dan CR.

3. Kesalahan Penulisan Partikel

a. Kudapun selamat dan bisa memakan gandum.

Kesalahan penulisan partikel oleh siswa yang berinisial D pada kalimat di atas terdapat pada penulisan partikel "pun" yang digabung dengan kata "kuda". Seharusnya partikel "pun" ditulis terpisah sesudah kata "kuda", seperti "kuda pun". Kesalahan yang sama juga terdapat pada siswa yang berinisial RH, ZH, dan KT.

b. Kemudian datang lah seekor tikus yang kemarin membantunya.

Kesalahan penulisan partikel oleh siswa yang berinisial AP pada kalimat di atas terdapat pada penulisan partikel "lah" yang dipisah dengan kata "datang". Seharusnya penulisan partikel "lah" digabung dengan kata sebelumnya, yaitu 
kata "datang" sehingga menjadi “datanglah". Kesalahan yang sama juga terdapat pada siswa yang berinisial TI, YE, MF dan EM.

Langkah-langkah yang perlu dilakukan untuk mengatasi kesalahan siswa kelas VII SMP Negeri Pembangunan Padang dalam menulis teks fabel, yaitu sebagai berikut.

1. Memotivasi siswa untuk lebih giat membaca.

2. Memberikan pemahaman terhadap siswa mengenai struktur dan unsur kebahasaan teks fabel.

3. Memperbaiki kesalahan siswa dalam menulis teks fabel.

4. Memberikan contoh yang benar sebelum menugaskan siswa menulis teks fabel.

\section{Simpulan dan Saran}

Penelitian ini membahas mengenai analisis struktur dan unsur kebahsaan (pemakaian huruf kapital, penulisan kata depan, dan penulisan partikel) dalam teks fabel karya siswa kelas VII SMP Negeri Pembangunan Padang. Berdasarkan dari hasil penelitian dan pembahasaan yang disampaikan, diperoleh simpulan sebagai berikut.

Pertama, struktur dalam teks fabel karya siswa VII SMP Negeri Pembangunan Padang sudah 99\% dibuat dengan tepat dan baik. Hal ini menunjukkan bahwa siswa kelas VII SMP Negeri Pembangunan Padang sudah sangat bagus membuat teks fabel dalam segi strukturnya.

Kedua, terdapat kesalahan unsur kebahasaan dalam teks fabel karya siswa VII SMP Negeri Pembangunan Padang, yaitu kesalahan pemakaian huruf kapital, kesalahan penulisan kata depan, dan kesalahan penulisan partikel. Kesalahan yang ditemukan meliputi, (1) kesalahan pemakaian huruf kapital sebanyak 175 kasus kesalahan, (2) kesalahan penulisan kata depan sebanyak 50 kasus kesalahan, dan (3) kesalahan penulisan partikel sebanyak 43 kasus kesalahan.

Ketiga, langkah-langkah untuk mengatasi terjadinya kesalahan menulis teks fabel siswa kelas VII SMP Negeri Pembangunan Padang adalah dengan memberikan motivasi pada siswa kelas 
VII SMP Negeri Pembangunan Padang untuk lebih banyak membaca. Memberikan pengetahuan mengenai unsur kebahasaan pada siswa kelas VII SMP Negeri Pembangunan Padang. Memperbaiki tulisan siswa kelas VII SMP Negeri Pembangunan Padang yang salah. Serta memberikan contoh yang benar sebelum menugaskan siswa membuat teks fabel.

\section{Daftar Pustaka}

Ermanto dan Emidar. 2011. Afiks Derivasi Per-/-An dalam Bahasa Indonesia:

Tinjauan dari Perspektif Morfologi Derivasi dan Infleksi. Jurnal Bahasa dan Seni. Vol. 12 No. 1. Hal. 23 - 34.

Reistanti, Agustina Putri. 2017. Analisis Kesalahan Berbahasa Pada Penulisan Cerita Fabel Oleh Siswa Kelas Viii E Di Smp 2 Muhammadiyah Surakarta. "Jurnal Kajian Linguistik dan Sastra", EISSN: 2541-2558, ISSN: 0852-9604 http://journals.ums.ac.id/index.php/K $\underline{\text { LS }}$ vol. 2 Nomor 2 Desember 2017. 126. Diunduh pada 10 Maret 2020.

Safitri, Anindya. 2018. Analisis Kesalahan Berbahasa Dalam Teks Fabel Karya Siswa Kelas Vii Smp Negeri 1 Gerung Tahun Pelajaran 2016-2017. "Jurnal Skripsi". Universitas Mataram. file:///C:/Users/HP\%2014bw517AU\%20AMD\%20E2/ Documents/Jurnal\%20\%20Anindya \%20Safitri\%20\%2528E1C113007\% 2529.pdf. Diunduh pada 9 Maret 2020.

Suhendar. 1992. Bahasa Indonesia Pengajaran dan Uji Keterampilan Menulis. Bandung: Pionir Jaya. 